\title{
PEMBUATAN BAHAN ACUAN BAKU PASIR BESI MENGGUNAKAN INTER-LABORATORY STUDY
}

\section{ESTABLISHMENT OF IRON SAND MATERIAL STANDARD USING INTER-LABORATORY STUDY}

\author{
Oleh: \\ Khoirun Nahar dan Dedeh Dinarsih \\ Pusat Sumber Daya Geologi \\ Jl. Soekarno Hatta No. 444 Bandung
}

\begin{abstract}
SARI
Pasir besi yang dijadikan sebagai bahan acuan baku (standard reference material)diperoleh dari pesisir pantai selatan Kabupaten Kulon Progo, Yogyakarta dan pesisir pantai selatan Kabupaten Ende, Nusa Tenggara Timur. Metode pembuatan bahan acuan bakumeliputi metode pengambilan dan penanganan conto di lapangan, preparasi conto di laboratorium, pelabelan, analisis kimia di delapan laboratorium terhadap conto pasir besi, serta metoda pengolahan dan analisis data secara statistik. Analisis kimia di delapan laboratorium terhadap empat jenis conto pasir besi menghasilkan bahan acuan baku pasir besi dengan konsentrasi (\% berat) berkisar antara $23,81 \%-50,46 \% \mathrm{Fe}$ total, $19,63 \%-43,16 \% \mathrm{Fe}_{2} \mathrm{O}_{3}, 19,90 \%-25,22 \% \mathrm{FeO}$, dan 3,74\% $7,60 \% \mathrm{TiO}_{2}$.
\end{abstract}

Kata kunci : pasir besi, laboratorium, bahan acuan baku.

\section{ABSTRACT}

The standard reference material was made by using iron sand samples taken from southern coast of Kabupaten Kulon Progo, Yogyakarta, and southern coast of Kabupaten Ende, Nusa Tenggara Timur. The methods applied in this works included sampling technique and samples processing in the field, samples preparation in the laboratory, samples labelling/tagging, chemical analysis of iron sands, and some statistical works for the chemical analysis data. Four samples which analized at 8 laboratories produced iron sand standard reference material with characteritics as follow $23.81-50.46$ (\%w) Fe total, $19.63-43.16(\% w) \mathrm{Fe}_{2} \mathrm{O}_{3}, 19.90-25.22$ (\%w) $\mathrm{FeO}$, and $3.74-7.60(\% \mathrm{w}) \mathrm{TiO}_{2}$.

Keywords :iron sand, laboratory, standard reference material.

\section{PENDAHULUAN}

Standard atau acuan dalam istilah kimia diartikan sebagai material atau bahan yang mengandung analit dengan konsentrasi yang telah diketahui. Bahan acuan tersebut memiliki peran penting di dalam proses analisa kimia karena fungsinya sebagai acuan untuk menentukan konsentrasi analit yang tidak diketahui atau untuk mengkalibrasi alat-alat ukur kimia. Dengan bahan acuan baku tersebut diharapkan hasil analisis kimia menjadi lebih akurat atau mendekati nilai sebenarnya (true value).
Penentuan keakuratan suatu proses analis kimia biasanya memerlukan validasi metode yang dilakukan dengan bahan acuan baku (standard) yang telah diketahui konsentrasinya.

Bahan acuan baku (standard reference material) sebagai pengendali jaminan mutu hasil analisa kimia bisa didapatkan dengan cara membeli dari lembaga tertentu, misalnya NIST dari Amerika, dan disebut sebagai CRM (certified reference material). $C R M$ tersebut dilengkapi dengan sertifikat 
yang berisi informasi tentang nama bahan dan konsentrasi kimia penyusun bahan. Namun biasanya CRM tersebut harganya sangat mahal dan ketersediaannya juga terbatas. Alternatif lain untuk penyediaan bahan acuan baku tersebut adalah dengan membuat sendiri, yang produknya biasa dikenal sebagai in house standard. Salah satu cara yang sudah dikenal untuk membuat bahan acuan baku adalah dengan cara pengujian antar laboratorium terhadap bahan yang akan dijadikan sebagai acuan.

Pasir besi yang dijadikan sebagai bahan acuan baku diperoleh dari pesisir pantai selatan Kabupaten Kulon Progo, Yogyakarta dan pesisir pantai selatan Kabupaten Ende, Nusa Tenggara Timur.

Tujuan penulisan makalah ini adalah untuk mengetahui akurasi dan presisi hasil analisis delapan laboratorium terhadap empat conto pasir besi yang dijadikan bahan acuan baku.

\section{Metodologi}

Metode pembuatan bahan acuan baku meliputi metode pengambilan dan penanganan conto di lapangan, preparasi conto di laboratorium, pelabelan, analisis kimia di delapan laboratorium terhadap conto pasir besi, serta metode pengolahan dan analisis data secara statistik.

Pada pasir besi yang dari pesisir pantai selatan Kabupaten Kulon Progo, Yogyakarta dan pesisir pantai selatan Kabupaten Ende, Nusa Tenggara Timur, dilakukan preparasi dilapangan untuk menghilangkan pengotornya, conto diambil seberat 20-30 Kg. Dari kegiatan ini diperoleh empat jenis conto dengan perkiraan kandungan Fe total yang bervariasi. Empat jenis conto ini masing-masing diberi kode IA, IIA, VA (didapat dari pesisir pantai selatan Kabupaten Kulon Progo), dan ENDE-5 yang didapatkan dari pesisir pantai selatan Kabupaten Ende. Pasir besi yang didapatkan selanjutnya dibagi menjadi dua bagian, satu bagian untuk dianalisis di laboratorium Pusat Sumber Daya Geologi (PSDG) dan conto yang sama di bagian lain untuk dianalisis di tujuh laboratorium lain, yaitu di laboratorium Pusat Survei Geologi (PSG) Bandung, Intertek Jakarta, Balai Bahan Besar dan Barang Teknik (B4T) Bandung, Balai Keramik Bandung, Pusat Penelitian dan Pengembangan Teknologi Mineral dan Batubara (Tekmira) Bandung,

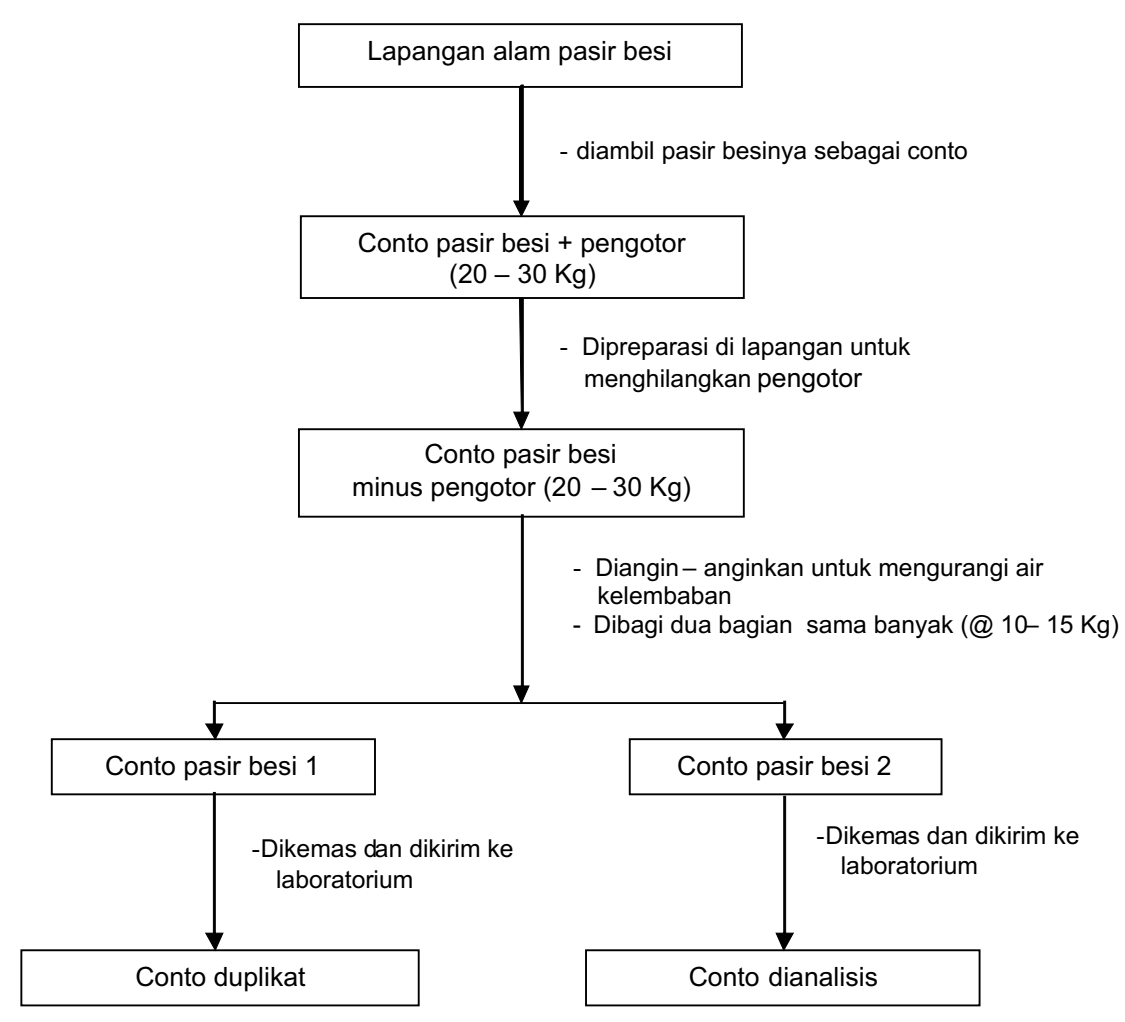

Gambar 1. Bagan alir pengambilan conto dan preparasi pasir besi. ${ }^{[4]}$ 
PT. Geoservices Bandung, dan Badan Tenaga Nuklir Nasional (Batan) Jakarta. Secara detail preparasi dan pembagian conto pasir besi dapat di lihat pada Gambar 1.

Pasir besi di laboratorium dilakukan preparasi digerus menggunakan alat pulveryzer atau tema mill sampai lolos saringan 150 mesh dan dipastikan homogenitasnya dengan menggunakan alat blending machine sampai homogen (sekitar 8 jam). Selanjutnya conto pasir besi dianalisis untuk ditentukan konsentrasi (\%) Fe total, $\mathrm{FeO}, \mathrm{Fe}_{2} \mathrm{O}_{3}, \mathrm{Al}_{2} \mathrm{O}_{3}, \mathrm{CaO}, \mathrm{MgO}, \mathrm{Na}_{2} \mathrm{O}$, $\mathrm{K}_{2} \mathrm{O}, \mathrm{MnO}, \mathrm{TiO}_{2}, \mathrm{H}_{2} \mathrm{O}$ (air kelembaban), Loss on Ignition $\left(\mathrm{L}_{\circ} \mathrm{l}\right)$, $\mathrm{S}$ total di delapan laboratorium yang berbeda. Data hasil analisis dari delapan laboratorium diolah secara statistik dan dianalisis dengan metoda in lierdan out lier.

\section{Hasil Analisis dan Pembahasan}

Masing-masing laboratorium yang dilibatkan dalam analisis kimia pasir besi ini menggunakan metoda yang biasa digunakan oleh laboratorium tersebut. Hasil

Tabel 1. Hasil analisis kimia conto pasir besi IA (dry base), Kulon Progo

\begin{tabular}{|c|c|c|c|c|c|c|c|c|c|c|c|c|c|c|c|}
\hline $\begin{array}{c}\text { LAB } \\
\text { PENGUJI }\end{array}$ & \multicolumn{15}{|c|}{ HASIL ANALISIS (\%) } \\
\hline PSG & 42,68 & 38,67 & 20,27 & 7,38 & 7,95 & 0,06 & 0,60 & 6,16 & 0,31 & 0,82 & 0,01 & 0,10 & 16,24 & 0,05 & - \\
\hline Intertek & 41,83 & 59,82 & 53,82 & 6,18 & 5,85 & 4,60 & 0,58 & 5,01 & 0,34 & 0,58 & 0,46 & 0,00 & 17,62 & 0,20 & 0,10 \\
\hline B4T & - & 60,48 & - & 9,75 & 0,09 & 1,50 & 1,93 & 1,87 & 0,03 & 0,04 & 0,01 & 0,01 & 24,28 & - & 0,00 \\
\hline Geoservices & 41,43 & 59,25 & - & 6,33 & 5,84 & 4,97 & 0,57 & 5,16 & 0,36 & 0,84 & 0,21 & 0,06 & 18,04 & 0,11 & $-1,92$ \\
\hline Batan & 39,26 & - & - & 3,47 & 3,68 & 2,80 & 0,38 & 15,60 & 0,18 & 0,36 & - & - & 0,65 & - & - \\
\hline PSDG & 41,59 & 36,03 & 21,16 & 6,68 & 6,22 & 4,90 & 0,59 & 5,25 & 0,32 & 0,70 & 0,21 & 0,02 & 16,52 & 0,22 & 0,52 \\
\hline
\end{tabular}

Tabel 2. Hasil analisis kimia conto pasir besi IIA (dry base), Kulon Progo

\begin{tabular}{|c|c|c|c|c|c|c|c|c|c|c|c|c|c|c|c|}
\hline \multirow{2}{*}{$\begin{array}{c}\text { LAB } \\
\text { PENGUJI }\end{array}$} & \multicolumn{15}{|c|}{ HASIL ANALISIS (\%) } \\
\hline & Fe total & $\mathrm{Fe}_{2} \mathrm{O}_{3}$ & $\mathrm{FeO}$ & $\mathrm{TiO}_{2}$ & $\mathrm{Al}_{2} \mathrm{O}_{3}$ & MgO & MnO & $\mathrm{CaO}$ & $\mathrm{K}_{2} \mathrm{O}$ & $\mathrm{Na}_{2} \mathrm{O}$ & $P$ total & $S$ total & $\mathrm{SiO}_{2}$ & $\mathrm{H}_{2} \mathrm{O}^{-}$ & LOI \\
\hline PSG & 22,78 & 19,05 & 12,26 & 3,93 & 12,87 & 0,06 & 0,51 & 11,01 & 0,66 & 2,20 & 0,01 & 0,20 & 33,87 & 0,08 & - \\
\hline Intertek & 23,79 & 34,03 & 30,61 & 3,42 & 9,21 & 6,39 & 0,46 & 9,00 & 0,73 & 1,39 & 0,39 & 0,01 & 35,17 & 0,10 & 0,10 \\
\hline B4T & - & 40,09 & - & 7,38 & 0,12 & 2,46 & 0,77 & 1,86 & 0,05 & 0,02 & 0,01 & 0,01 & 47,23 & - & - \\
\hline Balai Keramik & 34,45 & 32,82 & 14,76 & 7,27 & 2,04 & 0,40 & 0,05 & 0,93 & 0,79 & 2,94 & 0,01 & 0,18 & 35,82 & 0,77 & 0,02 \\
\hline Tekmira & 27,00 & 26,30 & 11,10 & 4,16 & 8,09 & 6,78 & 0,39 & 8,08 & 0,70 & 1,49 & - & - & 32,80 & 0,21 & - \\
\hline Geoservices & 24,77 & 35,42 & - & 3,55 & 9,21 & 6,76 & 0,45 & 9,13 & 0,76 & 1,61 & 0,18 & 0,03 & 35,70 & 0,01 & $-0,84$ \\
\hline Batan & 20,17 & - & - & 1,90 & 5,51 & 2,84 & 0,31 & 23,54 & 0,36 & 1,29 & - & - & 0,96 & - & - \\
\hline PSDG & 24,37 & 20,21 & 13,18 & 3,64 & 9,48 & 6,38 & 0,47 & 9,21 & 0,67 & 1,56 & 0,15 & 0,03 & 20,33 & 0,15 & 0,69 \\
\hline
\end{tabular}

Tabel 3. Hasil analisis kimia conto pasir besi VA (dry base), Kulon Progo

\begin{tabular}{|c|c|c|c|c|c|c|c|c|c|c|c|c|c|c|c|}
\hline \multirow{2}{*}{$\begin{array}{c}\text { LAB } \\
\text { PENGUJI }\end{array}$} & \multicolumn{15}{|c|}{ HASIL ANALISIS (\%) } \\
\hline & $\begin{array}{c}\mathrm{Fe} \\
\text { total }\end{array}$ & $\mathrm{Fe}_{2} \mathrm{O}_{3}$ & $\mathrm{FeO}$ & $\mathrm{TiO}_{2}$ & $\mathrm{Al}_{2} \mathrm{O}_{3}$ & MgO & $\mathrm{MnO}$ & $\mathrm{CaO}$ & $\mathrm{K}_{2} \mathrm{O}$ & $\mathrm{Na}_{2} \mathrm{O}$ & $\begin{array}{c}P \\
\text { total }\end{array}$ & $\begin{array}{c}S \\
\text { total }\end{array}$ & $\mathrm{SiO}_{2}$ & $\mathrm{H}_{2} \mathrm{O}^{-}$ & LOI \\
\hline PSG & 47,59 & 40,95 & 24,58 & 9,10 & 7,56 & 0,03 & 0,43 & 3,00 & 0,19 & 0,66 & 0,01 & 0,10 & 5,11 & 0,04 & - \\
\hline Intertek & 51,05 & 73,01 & 65,68 & 7,61 & 4,54 & 3,36 & 0,62 & 2,66 & 0,18 & 0,38 & 0,42 & 0,01 & 8,88 & 0,10 & 0,10 \\
\hline B4T & - & 74,27 & - & 9,98 & 0,17 & 1,25 & 2,52 & 0,94 & 0,04 & 0,05 & 0,01 & 0,01 & 10,75 & - & - \\
\hline Balai Keramik & 46,25 & 44,47 & 19,44 & 11,33 & 2,04 & 1,64 & 0,05 & 1,12 & 0,71 & 1,89 & 0,01 & 0,36 & 15,00 & 0,54 & 0,02 \\
\hline Tekmira & 52,60 & 57,60 & 15,81 & 9,28 & 4,13 & 3,52 & 0,55 & 2,43 & 0,16 & 0,61 & 0,15 & - & 5,58 & 0,14 & \\
\hline Geoservices & 49,99 & 71,48 & - & 7,87 & 4,56 & 3,74 & 0,62 & 2,73 & 0,22 & 0,62 & 0,20 & 0,08 & 9,30 & 0,10 & $-2,46$ \\
\hline Batan & 50,57 & - & - & 4,36 & 2,60 & 2,14 & 0,43 & 7,46 & 0,11 & 0,25 & - & - & 0,99 & - & \\
\hline PSDG & 50,97 & 44,06 & 25,86 & 7,69 & 4,92 & 3,53 & 0,63 & 2,47 & 0,20 & 0,48 & 0,17 & 0,05 & 9,36 & 0,19 & 0,51 \\
\hline
\end{tabular}


Tabel 4. Hasil analisis kimia conto pasir besi ENDE-5 (dry base), Ende

\begin{tabular}{|c|c|c|c|c|c|c|c|c|c|c|c|c|c|c|c|}
\hline \multirow{2}{*}{$\begin{array}{c}\text { LAB } \\
\text { PENGUJI }\end{array}$} & \multicolumn{15}{|c|}{ HASIL ANALISIS (\%) } \\
\hline & Fe total & $\mathrm{Fe}_{2} \mathrm{O}_{3}$ & $\mathrm{FeO}$ & $\mathrm{TiO}_{2}$ & $\mathrm{Al}_{2} \mathrm{O}_{3}$ & MgO & MnO & $\mathrm{CaO}$ & $\mathrm{K}_{2} \mathrm{O}$ & $\mathrm{Na}_{2} \mathrm{O}$ & $\begin{array}{c}P \\
\text { total }\end{array}$ & $S$ total & $\mathrm{SiO}_{2}$ & $\mathrm{H}_{2} \mathrm{O}^{-}$ & LOI \\
\hline PSG & 42,68 & 38,67 & 20,27 & 7,38 & 7,95 & 0,06 & 0,60 & 6,16 & 0,31 & 0,82 & 0,01 & 0,10 & 16,24 & 0,05 & - \\
\hline Intertek & 41,83 & 59,82 & 53,82 & 6,18 & 5,85 & 4,60 & 0,58 & 5,01 & 0,34 & 0,58 & 0,46 & 0,00 & 17,62 & 0,20 & 0,10 \\
\hline B4T & - & 61,12 & - & 9,37 & 0,13 & 2,02 & 1,03 & 2,42 & 0,06 & 0,04 & 0,01 & 0,01 & 23,78 & - & 0,00 \\
\hline $\begin{array}{l}\text { Balai } \\
\text { Keramik }\end{array}$ & 47,95 & 45,70 & 20,52 & 10,92 & 0,41 & 0,78 & 0,05 & 1,91 & 0,90 & 3,22 & 0,01 & 0,39 & 14,21 & 0,38 & 0,02 \\
\hline Tekmira & 47,50 & 39,00 & 25,50 & 7,91 & 3,09 & 9,15 & 0,36 & 1,24 & 0,10 & 0,39 & - & - & 12,45 & 0,15 & - \\
\hline Geoservices & 45,22 & 64,66 & - & 7,16 & 3,35 & 8,84 & 0,44 & 1,41 & 0,02 & 0,26 & 0,02 & 0,07 & 16,58 & 0,05 & $-2,66$ \\
\hline Batan & 43,70 & - & - & 3,95 & 1,88 & 5,07 & 0,31 & 5,33 & 0,02 & 0,07 & - & - & 1,47 & - & - \\
\hline PSDG & 46,71 & 35,72 & 27,85 & 7,58 & 3,72 & 8,42 & 0,46 & 1,38 & 0,05 & 0,12 & 0,02 & 0,06 & 13,17 & 0,06 & 0,56 \\
\hline
\end{tabular}

Tabel 5. Hasil uji pencilan data secara visual dari hasil analisis kimia conto pasir besi IA yang dilakukan oleh delapan laboratorium

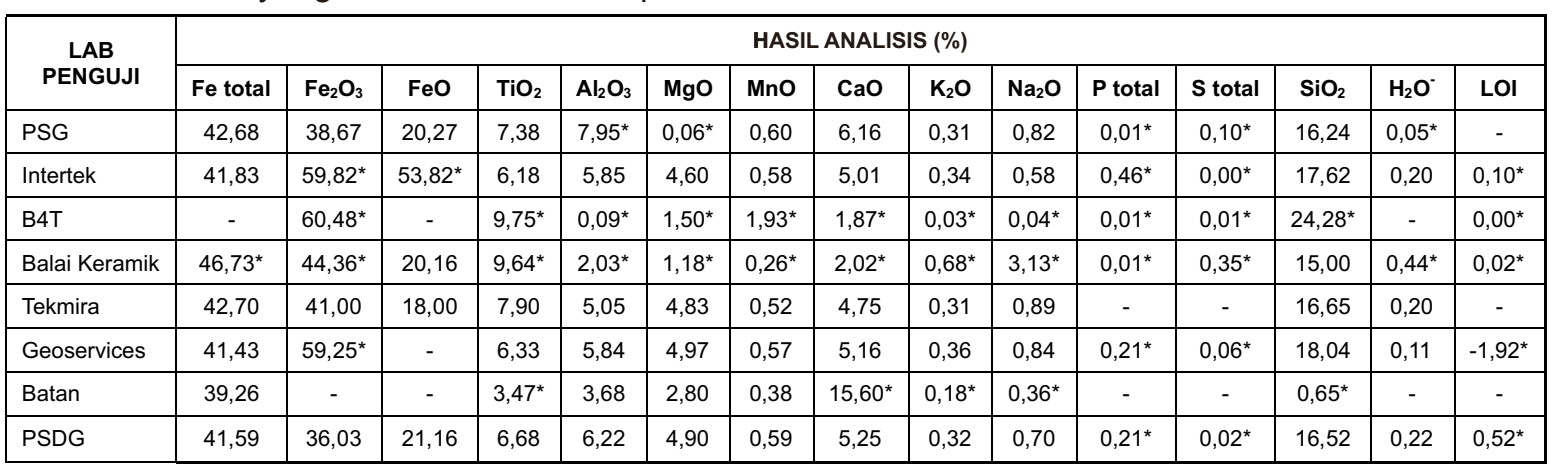

Keterangan : - penambahan tanda $\left(^{*}\right)$ pada data menunjukkan bahwa data tersebut tidak terpakai - tanda (-) pada kolom menunjukkan tidak ada data dari laboratorium penguji terkait

Tabel 6. Hasil uji secara Dikson dari data hasil analisis conto pasir besi IA

\begin{tabular}{|c|c|c|c|c|c|c|c|c|c|c|c|c|c|c|c|}
\hline \multirow{2}{*}{$\begin{array}{c}\text { LAB } \\
\text { PENGUJI }\end{array}$} & \multicolumn{15}{|c|}{ HASIL ANALISIS (\%) } \\
\hline & Fe total & $\mathrm{Fe}_{2} \mathrm{O}_{3}$ & $\mathrm{FeO}$ & $\mathrm{TiO}_{2}$ & $\mathrm{Al}_{2} \mathrm{O}_{3}$ & $\mathrm{MgO}$ & MnO & $\mathrm{CaO}$ & $\mathrm{K}_{2} \mathrm{O}$ & $\mathrm{Na}_{2} \mathrm{O}$ & P total & $S$ total & $\mathrm{SiO}_{2}$ & $\mathrm{H}_{2} \mathrm{O}-$ & LOI \\
\hline PSG & 42,68 & 38,67 & 20,27 & 7,38 & * & * & 0,60 & 6,16 & 0,31 & 0,82 & 0,01 & 0,10 & 16,24 & * & \\
\hline Intertek & 41,83 & * & * & 6,18 & 5,85 & 4,60 & 0,58 & 5,01 & 0,34 & 0,58 & 0,46 & 0,00 & 17,62 & 0,20 & 0,10 \\
\hline B4T & & * & & * & * & * & * & * & * & * & 0,01 & 0,01 & * & & 0,00 \\
\hline Balai Keramik & * & * & 20,16 & * & * & * & * & * & * & * & 0,01 & 0,35 & 15,00 & * & 0,02 \\
\hline Tekmira & 42,70 & 41,00 & 18,00 & 7,90 & 5,05 & 4,83 & 0,52 & 4,75 & 0,31 & 0,89 & & & 16,65 & 0,20 & \\
\hline Geoservices & 41,43 & * & & 6,33 & 5,84 & 4,97 & 0,57 & 5,16 & 0,36 & 0,84 & 0,21 & 0,06 & 18,04 & 0,11 & $-1,92$ \\
\hline Batan & $39,26^{*}$ & & & * & * & $2,80^{*}$ & $0,38^{*}$ & * & * & * & & & * & & \\
\hline PSDG & 41,59 & 36,03 & 21,16 & 6,68 & 6,22 & 4,90 & 0,59 & 5,25 & 0,32 & 0,70 & 0,21 & 0,02 & 16,52 & 0,22 & 0,52 \\
\hline
\end{tabular}

analisis kimia dari empat jenis pasir besi ini disajikan dalam Tabel 1 sampai Tabel 3 hasil analisis conto pasir besi dari Daerah Kulon Progo, Yogyakarta dan Tabel 4 hasil analisis pasir besi dari Daerah Ende, Nusa Tenggara Timur.

Hasil analisis kimia yang cukup bervariasi selanjutnya diolah secara statistik dengan tujuan untuk mendapatkan hasil angka konsentrasi analit yang mendekati nilai sesungguhnya. Uji statistik yang dilakukan terhadap data hasil analisa kimia sebagaimana tersebut di atas meliputi uji rataan, simpangan baku, presisi internal/eksternal, pencilan data (visual dan Dikson), out-lier/in-lier, dengan alat bantu perangkat lunak Microsoft Office Excel.

Data yang didapatkan selanjutnya diseleksi untuk menghilangkan hasil pengukuran yang secara ekstrim berbeda. Hal ini dilakukan dengan cara pencilan visual dan uji Dikson. Hasil uji pencilan data hasil analisa kimia conto pasir besi IA secara visual ditunjukkandalam Tabel 5.

Hasil uji pencilan data secara visual dari hasil analisa kimia conto pasir besi IA 
menunjukkan bahwa data yang bagus terdapat pada hasil pengukuran $\mathrm{Fe}$ total, $\mathrm{TiO}_{2}, \mathrm{MgO}, \mathrm{MnO}$, dan $\mathrm{SiO}_{2}$. Hasil pengukuran $\mathrm{P}$ total, $\mathrm{S}$ total, dan $\mathrm{L}_{\mathrm{o}}$ l tidak bisa diolah karena variansinya terlalu besar.

Selanjutnya data hasil uji pencilan secara visual dari conto pasir besi IA dipilahpilah lagi menggunakan uji Dikson. Uji ini dilakukan dengan cara terlebih dahulu mengurutkan data dari data terkecil sampai terbesar.

Hasil uji pencilan data secara visual dari hasil analisis kimia conto pasir besi IIA menunjukkan bahwa data yang bagus terdapat pada hasil pengukuran $\mathrm{Fe}$ total, $\mathrm{K}_{2} \mathrm{O}$, dan $\mathrm{Na}_{2} \mathrm{O}$. Hasil pengukuran $\mathrm{P}$ total, $\mathrm{S}$ total, $\mathrm{H}_{2} \mathrm{O}$, dan LOI tidak bisa diolah karena variansinya terlalu besar.

Selanjutnya data hasil uji pencilan

Tabel 7. Hasil uji pencilan data secara visual dari hasil analisis kimia conto pasir besi IIA yang dilakukan oleh delapan laboratorium

\begin{tabular}{|c|c|c|c|c|c|c|c|c|c|c|c|c|c|c|c|}
\hline \multirow{2}{*}{$\begin{array}{c}\text { LAB } \\
\text { PENGUJI }\end{array}$} & \multicolumn{15}{|c|}{ HASIL ANALISIS (\%) } \\
\hline & Fe total & $\mathrm{Fe}_{2} \mathrm{O}_{3}$ & $\mathrm{FeO}$ & $\mathrm{TiO}_{2}$ & $\mathrm{Al}_{2} \mathrm{O}_{3}$ & MgO & MnO & $\mathrm{CaO}$ & $\mathrm{K}_{2} \mathrm{O}$ & $\mathrm{Na}_{2} \mathrm{O}$ & $P$ total & $S$ total & $\mathrm{SiO}_{2}$ & $\mathrm{H}_{2} \mathrm{O}^{-}$ & LOI \\
\hline PSG & 22,78 & 19,05 & 12,26 & 3,93 & $12,87^{*}$ & $0,06^{*}$ & 0,51 & 11,01 & 0,66 & 2,20 & $0,01^{*}$ & $0,20^{*}$ & 33,87 & $0,08^{*}$ & - \\
\hline Intertek & 23,79 & $34,03^{*}$ & $30,61^{*}$ & 3,42 & 9,21 & 6,39 & 0,46 & 9,00 & 0,73 & 1,39 & $0,39^{*}$ & $0,01^{*}$ & 35,17 & $0,10^{*}$ & 0,10 \\
\hline B4T & - & $40,09^{*}$ & - & $7,38^{*}$ & $0,12^{*}$ & $2,46^{*}$ & $0,77^{*}$ & $1,86^{*}$ & $0,05^{*}$ & $0,02^{*}$ & $0,01^{*}$ & $0,01^{*}$ & $47,23^{*}$ & - & - \\
\hline Balai Keramik & $34,45^{\star}$ & $32,82^{*}$ & 14,76 & $7,27^{*}$ & $2,04^{*}$ & $0,40^{*}$ & $0,05^{*}$ & $0,93^{*}$ & 0,79 & $2,94^{*}$ & $0,01^{*}$ & $0,18^{*}$ & 35,82 & $0,77^{*}$ & 0,02 \\
\hline Tekmira & 27,00 & $26,30^{*}$ & 11,10 & 4,16 & 8,09 & 6,78 & 0,39 & 8,08 & 0,70 & 1,49 & - & - & 32,80 & $0,21^{*}$ & - \\
\hline Geoservices & 24,77 & $35,42^{*}$ & - & 3,55 & 9,21 & 6,76 & 0,45 & 9,13 & 0,76 & 1,61 & $0,18^{*}$ & $0,03^{*}$ & 35,70 & $0,01^{*}$ & $-0,84$ \\
\hline Batan & 20,17 & - & - & $1,90^{*}$ & 5,51 & $2,84^{*}$ & $0,31^{*}$ & $23,54^{*}$ & $0,36^{*}$ & 1,29 & - & - & $0,96^{*}$ & - & - \\
\hline PSDG & 24,37 & 20,21 & 13,18 & 3,64 & 9,48 & 6,38 & 0,47 & 9,21 & 0,67 & 1,56 & $0,15^{\star}$ & $0,03^{*}$ & 34,28 & $0,15^{*}$ & 0,69 \\
\hline
\end{tabular}

Keterangan :- penambahan tanda (*) pada data menunjukkan bahwa data tersebut tidak terpakai - tanda (-) pada kolom menunjukkan tidak ada data dari laboratorium penguji terkait

Tabel 8. Hasil uji secara Dikson dari data hasil analisis kimia conto pasir besi IIA

\begin{tabular}{|c|c|c|c|c|c|c|c|c|c|c|c|c|c|c|c|}
\hline \multirow{2}{*}{$\begin{array}{c}\text { LAB } \\
\text { PENGUJI }\end{array}$} & \multicolumn{15}{|c|}{ HASIL ANALISIS } \\
\hline & Fe total & $\mathrm{Fe}_{2} \mathrm{O}_{3}$ & $\mathrm{FeO}$ & $\mathrm{TiO}_{2}$ & $\mathrm{Al}_{2} \mathrm{O}_{3}$ & MgO & $\mathrm{MnO}$ & $\mathrm{CaO}$ & $\mathrm{K}_{2} \mathrm{O}$ & $\mathrm{Na}_{2} \mathrm{O}$ & $P$ total & $S$ total & $\mathrm{SiO}_{2}$ & $\mathrm{H}_{2} \mathrm{O}-$ & LOI \\
\hline PSG & 22,78 & 19,05 & 12,26 & 3,93 & * & * & 0,51 & 11,01 & 0,66 & $2,20^{*}$ & 0,01 & 0,20 & 33,87 & 0,08 & \\
\hline Intertek & 23,79 & * & * & 3,42 & 9,21 & 6,39 & 0,46 & 9,00 & 0,73 & 1,39 & 0,39 & 0,01 & 35,17 & 0,10 & 0,10 \\
\hline B4T & & * & & * & * & * & * & * & * & * & 0,01 & 0,01 & * & & \\
\hline Balai Keramik & * & * & 14,76 & * & * & * & * & * & 0,79 & * & 0,01 & 0,18 & 35,82 & 0,77 & 0,02 \\
\hline Tekmira & 27,00 & $26,3^{*}$ & 11,10 & 4,16 & 8,09 & 6,78 & 0,39 & 8,08 & 0,70 & 1,49 & & & 32,80 & 0,21 & \\
\hline Geoservices & 24,77 & * & & 3,55 & 9,21 & 6,76 & 0,45 & 9,13 & 0,76 & 1,61 & 0,18 & 0,03 & 35,70 & 0,01 & $-0,84$ \\
\hline Batan & 20,17 & & & * & 5,51 & $2,84^{*}$ & 0,31 & * & * & 1,29 & & & * & & \\
\hline PSDG & 24,37 & 20,21 & 13,18 & 3,64 & 9,48 & 6,38 & 0,47 & 9,21 & 0,67 & 1,56 & 0,15 & 0,03 & 34,28 & 0,15 & 0,69 \\
\hline
\end{tabular}

Tabel 9. Hasil uji pencilan data secara visual dari hasil analisis kimia conto pasir besi VA yang dilakukan oleh delapan laboratorium

\begin{tabular}{|c|c|c|c|c|c|c|c|c|c|c|c|c|c|c|c|}
\hline $\begin{array}{c}\text { LAB } \\
\text { PENGUJI }\end{array}$ & \multicolumn{15}{|c|}{ HASIL ANALISIS (\%) } \\
\hline PSG & 47,59 & 40,95 & 24,58 & 9,10 & $7,56^{*}$ & $0,03^{*}$ & 0,43 & 3,00 & 0,19 & 0,66 & $0,01^{*}$ & $0,10^{*}$ & $5,11^{*}$ & $0,04^{*}$ & - \\
\hline B4T & - & $74,27^{*}$ & - & 9,98 & $0,17^{*}$ & $1,25^{*}$ & $2,52^{*}$ & $0,94^{*}$ & $0,04^{*}$ & $0,05^{*}$ & $0,01^{*}$ & $0,01^{*}$ & 10,75 & - & - \\
\hline Balai Keramik & $46,25^{\star}$ & 44,47 & $19,44^{*}$ & $11,33^{*}$ & $2,04^{*}$ & $1,64^{*}$ & $0,05^{\star}$ & 1,12 & $0,71^{*}$ & $1,89^{*}$ & $0,01^{*}$ & $0,36^{*}$ & $15,00^{*}$ & $0,54^{*}$ & 0,02 \\
\hline Geoservices & 49,99 & $71,48^{*}$ & - & 7,87 & 4,56 & 3,74 & 0,62 & 2,73 & 0,22 & 0,62 & $0,20^{*}$ & $0,08^{*}$ & 9,30 & $0,10^{*}$ & $-2,46$ \\
\hline Batan & 50,57 & - & - & $4,36^{*}$ & $2,60^{*}$ & 2,14 & 0,43 & $7,46^{*}$ & 0,11 & $0,25^{*}$ & - & - & $0,99^{*}$ & - & - \\
\hline PSDG & 50,97 & 44,06 & 25,86 & 7,69 & 4,92 & 3,53 & 0,63 & 2,47 & 0,20 & 0,48 & $0,17^{*}$ & $0,05^{*}$ & 9,36 & $0,19^{*}$ & 0,51 \\
\hline
\end{tabular}

Keterangan : - penambahan tanda $\left({ }^{*}\right)$ pada data menunjukkan bahwa data tersebut tidak terpakai - tanda (-) pada kolom menunjukkan tidak ada data dari laboratorium penguji terkait 
Hasil uji pencilan data secara visual dari hasil analisa kimia conto pasir besi VA menunjukkan bahwa data yang bagus terdapat pada hasil pengukuran $\mathrm{Fe}$ total, $\mathrm{TiO}_{2}, \mathrm{MnO}, \mathrm{CaO}$, dan $\mathrm{K}_{2} \mathrm{O}$. Hasil pengukuran $\mathrm{P}$ total, $\mathrm{S}$ total, $\mathrm{H}_{2} \mathrm{O}$, dan $\mathrm{L}_{\mathrm{O}} \mathrm{l}$ tidak bisa diolah karena variansinya terlalu besar.Selanjutnya data hasil uji pencilan secara visual dari conto pasir besi VA dipilahpilah lagi menggunakan uji Dikson.

Hasil uji pencilan data secara visual dari hasil analisa kimia conto pasir besi ENDE-5 menunjukkan bahwa data yang bagus terdapat pada hasil pengukuran $\mathrm{TiO}_{2}$ dan $\mathrm{SiO}_{2}$ saja. Hasil pengukuran $\mathrm{K}_{2} \mathrm{O}, \mathrm{Na}_{2} \mathrm{O}, \mathrm{S}$ total, $\mathrm{H}_{2} \mathrm{O}$, dan $\mathrm{L}_{0}$ l tidak bisa diolah karena variansinya terlalu besar.

Data yang didapatkan dari pencilan secara visual selanjutnya dipilah-pilah lagi menggunakan uji secara Dikson. Uji ini dilakukan dengan cara mengurutkan terlebih dulu dari data terkecil sampai terbesar.

Uji rataan, uji simpangan baku, uji presisi eksternal, dan penentuan in-lier/out- lier.

Uji-uji ini dilakukan terhadap data hasil analisa kimia yang lolos seleksi dari uji pencilan data secara visual dan uji Dikson. Uji ini dilakukan dengan cara menghitung nilai rata-rata, simpangan baku, serta presisi dari data yang lolos seleksi dari dua uji tersebut di atas. Dari data nilai rata-rata dan presisi, selanjutnya dapat ditentukan data yang in-lier/out-lier.

\section{Contopasir besi IA}

Data hasil uji presisi eksternal hasil analisa kimia conto pasir besi IA ditunjukkan dalam Tabel 13, sedangkan kurva yang memperlihatkan in-lier/out-lier data hasil pengukuran $\mathrm{Fe}$ total pada conto pasir besi $1 \mathrm{~A}$ ditunjukkan dalam Gambar 2. Kurva yang memperlihatkan in-lier/out-lier data hasil pengukuran $\mathrm{TiO}_{2}$ pada conto pasir besi $1 \mathrm{~A}$ ditunjukkan dalam Gambar 3. Kurva yang memperlihatkan in-lier/out-lier data hasil pengukuran $\mathrm{SiO}_{2}$ pada conto pasir besi $1 \mathrm{~A}$ ditunjukkan dalam Gambar 4. Kurva yang

Tabel 10. Hasil uji secara Dikson dari data hasil analisis conto pasir besi VA

\begin{tabular}{|c|c|c|c|c|c|c|c|c|c|c|c|c|c|c|c|}
\hline \multirow{2}{*}{$\begin{array}{c}\text { LAB } \\
\text { PENGUJI }\end{array}$} & \multicolumn{15}{|c|}{ HASIL ANALISIS (\%) } \\
\hline & Fe total & $\mathrm{Fe}_{2} \mathrm{O}_{3}$ & $\mathrm{FeO}$ & $\mathrm{TiO}_{2}$ & $\mathrm{Al}_{2} \mathrm{O}_{3}$ & MgO & MnO & $\mathrm{CaO}$ & $\mathrm{K}_{2} \mathrm{O}$ & $\mathrm{Na}_{2} \mathrm{O}$ & P total & $S$ total & $\mathrm{SiO}_{2}$ & $\mathrm{H}_{2} \mathrm{O}^{-}$ & LOI \\
\hline PSG & 47,59 & 40,95 & 24,58 & 9,10 & * & * & 0,43 & 3,00 & 0,19 & 0,66 & 0,01 & 0,10 & * & 0,04 & \\
\hline Intertek & 51,05 & * & * & 7,61 & 4,54 & 3,36 & 0,62 & 2,66 & 0,18 & * & 0,42 & 0,01 & 8,88 & 0,10 & 0,10 \\
\hline B4T & & * & & 9,98 & * & * & * & * & * & * & 0,01 & 0,01 & 10,75 & & \\
\hline Balai Keramik & * & 44,47 & * & * & * & * & * & * & * & * & 0,01 & 0,36 & * & 0,54 & 0,02 \\
\hline Tekmira & 52,60 & * & * & 9,28 & 4,13 & 3,52 & 0,55 & 2,43 & 0,16 & 0,61 & 0,15 & & * & 0,14 & \\
\hline Geoservices & 49,99 & * & & 7,87 & 4,56 & 3,74 & 0,62 & 2,73 & 0,22 & 0,62 & 0,20 & 0,08 & 9,30 & 0,10 & $-2,46$ \\
\hline Batan & 50,57 & & & * & 2,60 & $2,14^{*}$ & 0,43 & * & 0,11 & * & & & * & & \\
\hline PSDG & 50,97 & 44,06 & 25,86 & 7,69 & 4,92 & 3,53 & 0,63 & 2,47 & 0,20 & 0,48 & 0,17 & 0,05 & 9,36 & 0,19 & 0,51 \\
\hline
\end{tabular}

Hasil uji pencilan data hasil analisa kimia conto pasir besi ENDE-5 secara visual ditunjukkan dalam Tabel 11.

Tabel 11. Hasil uji pencilan data secara visual dari hasil analisis kimia conto pasir besi ENDE-5 yang dilakukan oleh delapan laboratorium

\begin{tabular}{|c|c|c|c|c|c|c|c|c|c|c|c|c|c|c|c|}
\hline \multirow{2}{*}{$\begin{array}{c}\text { LAB } \\
\text { PENGUJI }\end{array}$} & \multicolumn{15}{|c|}{ HASIL ANALISIS (\%) } \\
\hline & Fe total & $\mathrm{Fe}_{2} \mathrm{O}_{3}$ & $\mathrm{FeO}$ & $\mathrm{TiO}_{2}$ & $\mathrm{Al}_{2} \mathrm{O}_{3}$ & $\mathrm{MgO}$ & MnO & $\mathrm{CaO}$ & $\mathrm{K}_{2} \mathrm{O}$ & $\mathrm{Na}_{2} \mathrm{O}$ & $P$ total & $S$ total & $\mathrm{SiO}_{2}$ & $\mathrm{H}_{2} \mathrm{O}^{-}$ & LOI \\
\hline PSG & $42,68^{*}$ & 38,67 & 20,27 & 7,38 & $7,95^{\star}$ & $0,06^{*}$ & 0,60 & $6,16^{*}$ & $0,31^{*}$ & $0,82^{*}$ & 0,01 & $0,10^{*}$ & 16,24 & $0,05^{\star}$ & - \\
\hline Intertek & $41,83^{*}$ & $59,82^{*}$ & $53,82^{*}$ & 6,18 & 5,85 & $4,60^{*}$ & 0,58 & $5,01^{*}$ & $0,34^{*}$ & $0,58^{*}$ & $0,46^{*}$ & $0,00^{*}$ & 17,62 & $0,20^{*}$ & 0,10 \\
\hline B4T & - & $61,12^{*}$ & - & 9,37 & $0,13^{*}$ & $2,02^{*}$ & $1,03^{*}$ & 2,42 & $0,06^{*}$ & $0,04^{*}$ & 0,01 & $0,01^{*}$ & $23,78^{*}$ & - & 0,00 \\
\hline Balai Keramik & 47,95 & $45,70^{*}$ & 20,52 & $10,92^{*}$ & $0,41^{*}$ & $0,78^{*}$ & $0,05^{\star}$ & 1,91 & $0,90^{*}$ & $3,22^{*}$ & 0,01 & $0,39^{*}$ & 14,21 & $0,38^{*}$ & 0,02 \\
\hline Tekmira & 47,50 & 39,00 & 25,50 & 7,91 & 3,09 & 9,15 & 0,36 & 1,24 & $0,10^{*}$ & $0,39^{*}$ & - & - & 12,45 & $0,15^{*}$ & - \\
\hline Geoservices & 45,22 & $64,66^{*}$ & - & 7,16 & 3,35 & 8,84 & 0,44 & 1,41 & $0,02^{*}$ & $0,26^{*}$ & 0,02 & $0,07^{*}$ & 16,58 & $0,05^{\star}$ & $-2,66$ \\
\hline Batan & $43,70^{*}$ & - & - & $3,95^{*}$ & 1,88 & 5,07 & $0,31^{*}$ & $5,33^{*}$ & $0,02^{*}$ & $0,07^{*}$ & & - & $1,47^{*}$ & - & - \\
\hline PSDG & 46,71 & 35,72 & 27,85 & 7,58 & 3,72 & 8,42 & 0,46 & 1,38 & $0,05^{\star}$ & $0,12^{*}$ & 0,02 & $0,06^{*}$ & 13,17 & $0,06^{*}$ & 0,56 \\
\hline
\end{tabular}

Keterangan : - penambahan tanda $\left(^{*}\right)$ pada data menunjukkan bahwa data tersebut tidak terpakai - tanda (-) pada kolom menunjukkan tidak ada data dari laboratorium penguji terkait 


\section{MAKALAH ILMIAH}

memperlihatkan in-lier/out-lier data hasil pengukuran $\mathrm{MgO}$ pada conto pasir besi $1 \mathrm{~A}$ ditunjukkan dalam Gambar 5. Dan kurva yang memperlihatkan in-lier/out-lier data hasil pengukuran $\mathrm{MnO}$ pada conto pasir besi
1 A ditunjukkan dalam Gambar 6.

Hasil uji secara Dikson dari data hasil analisa conto pasir besi ENDE-5 selanjutnya dirangkum dalam Tabel 12.

Tabel 12.Hasil uji secara Dikson dari data hasil analisis conto pasir besi ENDE-5.

\begin{tabular}{|c|c|c|c|c|c|c|c|c|c|c|c|c|c|c|c|}
\hline \multirow{2}{*}{$\begin{array}{c}\text { LAB } \\
\text { PENGUJI }\end{array}$} & \multicolumn{15}{|c|}{ HASIL ANALISIS } \\
\hline & Fe total & $\mathrm{Fe}_{2} \mathrm{O}_{3}$ & $\mathrm{FeO}$ & $\mathrm{TiO}_{2}$ & $\mathrm{Al}_{2} \mathrm{O}_{3}$ & MgO & $\mathrm{MnO}$ & $\mathrm{CaO}$ & $\mathrm{K}_{2} \mathrm{O}$ & $\mathrm{Na}_{2} \mathrm{O}$ & P total & $S$ total & $\mathrm{SiO}_{2}$ & $\mathrm{H}_{2} \mathrm{O}^{-}$ & LOI \\
\hline PSG & * & 38,67 & 20,27 & 7,38 & * & * & 0,60 & * & 0,31 & 0,82 & 0,01 & 0,10 & 16,24 & 0,05 & \\
\hline Intertek & * & * & * & 6,18 & 5,85 & * & 0,58 & * & 0,34 & 0,58 & * & 0,00 & 17,62 & 0,20 & 0,10 \\
\hline B4T & & * & & 9,37 & * & * & * & 2,42 & 0,06 & 0,04 & 0,01 & 0,01 & * & & 0,00 \\
\hline Balai Keramik & 47,95 & * & 20,52 & * & * & * & * & 1,91 & 0,90 & 3,22 & 0,01 & 0,39 & 14,21 & 0,38 & 0,02 \\
\hline Tekmira & 47,50 & 39,00 & 25,50 & 7,91 & 3,09 & 9,15 & 0,36 & 1,24 & 0,10 & 0,39 & & & 12,45 & 0,15 & \\
\hline Geoservices & 45,22 & * & & 7,16 & 3,35 & 8,84 & 0,44 & 1,41 & 0,02 & 0,26 & 0,02 & 0,07 & 16,58 & 0,05 & $-2,66$ \\
\hline Batan & * & & & * & 1,88 & 5,07 & * & * & 0,02 & 0,07 & & & * & & \\
\hline PSDG & 46,71 & 35,72 & 27,85 & 7,58 & 3,72 & 8,42 & 0,46 & 1,38 & 0,05 & 0,12 & 0,02 & 0,06 & 13,17 & 0,06 & 0,56 \\
\hline
\end{tabular}

Tabel 13.presisi eksternal hasil analisis kimia conto pasir besi IA

\begin{tabular}{|c|c|c|c|c|c|c|c|c|c|c|c|c|c|c|c|}
\hline \multirow{2}{*}{$\begin{array}{c}\text { LAB } \\
\text { PENGUJI }\end{array}$} & \multicolumn{15}{|c|}{ HASIL ANALISIS (\%) } \\
\hline & Fe total & $\mathrm{Fe}_{2} \mathrm{O}_{3}$ & $\mathrm{FeO}$ & $\mathrm{TiO}_{2}$ & $\mathrm{Al}_{2} \mathrm{O}_{3}$ & MgO & MnO & $\mathrm{CaO}$ & $\mathrm{K}_{2} \mathrm{O}$ & $\mathrm{Na}_{2} \mathrm{O}$ & P total & $S$ total & $\mathrm{SiO}_{2}$ & $\mathrm{H}_{2} \mathrm{O}^{-}$ & LOI \\
\hline PSG & 42,68 & 38,67 & 20,27 & 7,38 & * & * & 0,60 & 6,16 & 0,31 & 0,82 & 0,01 & 0,10 & 16,24 & * & - \\
\hline Intertek & 41,83 & * & * & 6,18 & 5,85 & 4,60 & 0,58 & 5,01 & 0,34 & 0,58 & 0,46 & 0,00 & 17,62 & 0,20 & 0,10 \\
\hline B4T & - & * & - & * & * & * & * & * & * & * & 0,01 & 0,01 & * & - & 0,00 \\
\hline Balai Keramik & * & * & 20,16 & * & * & * & * & * & * & * & 0,01 & 0,35 & 15,00 & * & 0,02 \\
\hline Tekmira & 42,70 & 41,00 & 18,00 & 7,90 & 5,05 & 4,83 & 0,52 & 4,75 & 0,31 & 0,89 & - & - & 16,65 & 0,20 & - \\
\hline Geoservices & 41,43 & * & - & 6,33 & 5,84 & 4,97 & 0,57 & 5,16 & 0,36 & 0,84 & 0,21 & 0,06 & 18,04 & 0,11 & $-1,92$ \\
\hline Batan & $39,26^{*}$ & - & - & * & * & $2,80^{*}$ & $0,38^{*}$ & * & * & * & - & - & * & - & - \\
\hline PSDG & 41,59 & 36,03 & 21,16 & 6,68 & 6,22 & 4,90 & 0,59 & 5,25 & 0,32 & 0,70 & 0,21 & 0,02 & 16,52 & 0,22 & 0,52 \\
\hline Rataan $=$ & 42,05 & 38,57 & 19,90 & 6,89 & 5,74 & 4,83 & 0,57 & 5,27 & 0,33 & 0,77 & 0,21 & 0,02 & 16,68 & 0,18 & 0,52 \\
\hline$S D=$ & 0,605 & - & 1,342 & 0,728 & 0,493 & 0,161 & 0,031 & 0,534 & 0,022 & 0,125 & - & - & 1,075 & - & - \\
\hline $\begin{array}{c}\text { Presisi }= \\
\text { (sser } \quad n ; \alpha / 2 / \sqrt{n})\end{array}$ & 0,695 & - & 1,865 & 0,652 & 0,633 & 0,223 & 0,036 & 0,614 & 0,025 & 0,144 & - & - & 1,075 & - & - \\
\hline$t_{n ; 0.025}$ & 2,57 & - & 2,78 & 2,37 & 2,57 & 2,78 & 2,57 & 2,57 & 2,57 & 2,57 & - & - & 2,45 & - & - \\
\hline $\mathrm{n}$ & 5 & - & 4 & 7 & 4 & 4 & 5 & 5 & 5 & 5 & - & - & 6 & - & - \\
\hline
\end{tabular}

Dari data di atas kemudian ditentukan data yang in-lier/out-lier.

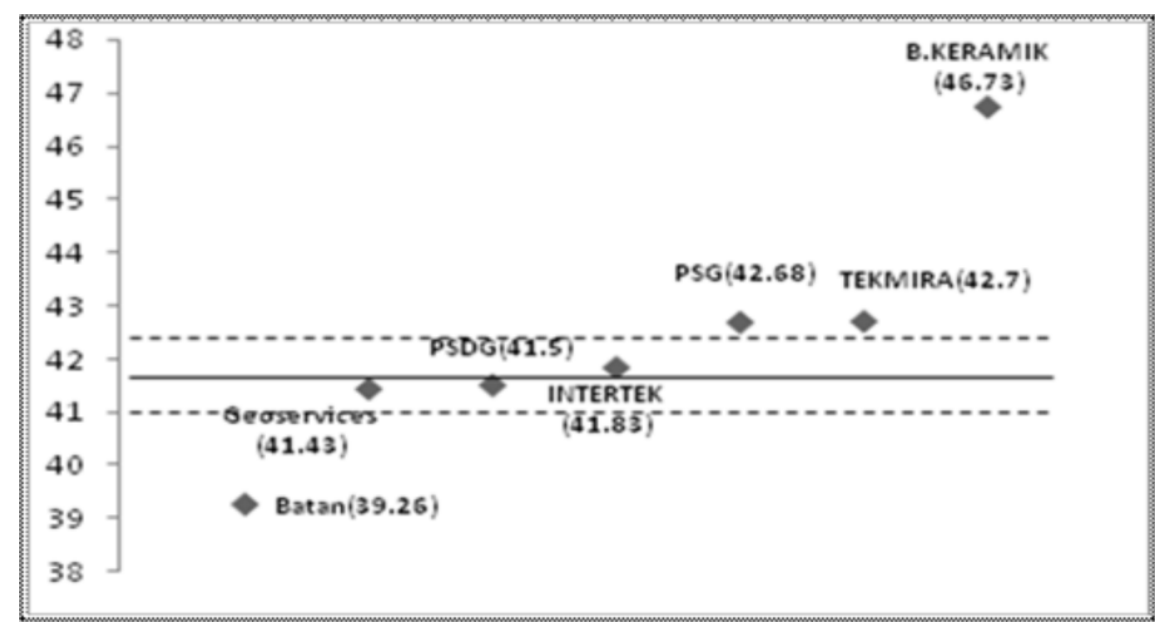

Gambar 2. Kurva in-lier/out-lier data hasil pengukuran Fe total conto pasir besi IA 


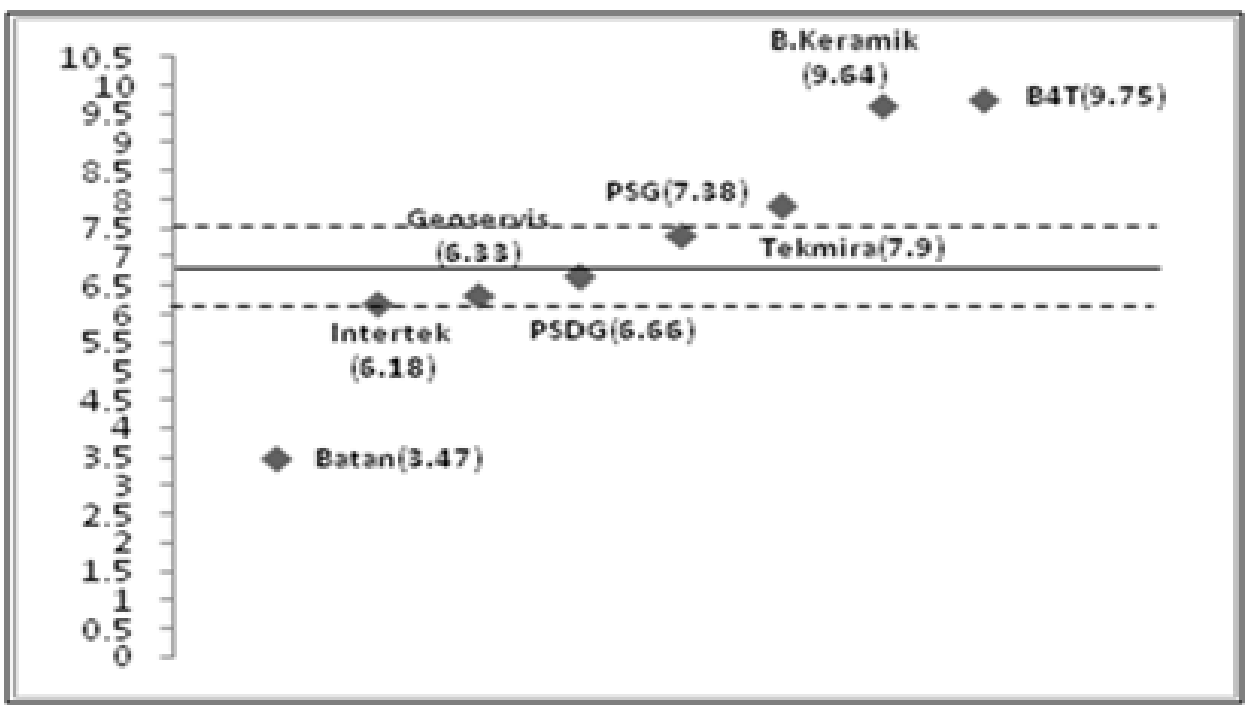

Gambar 3. Kurva in-lier/out-lier data hasil pengukuran $\mathrm{TiO}_{2}$ conto pasir besi IA

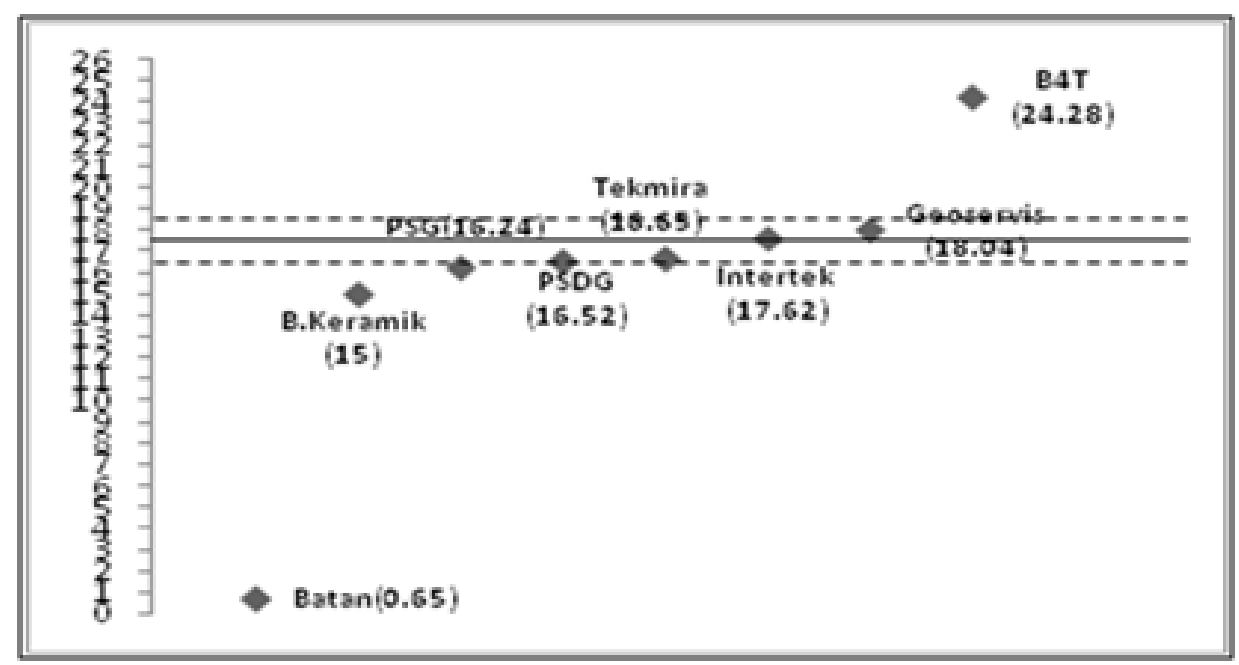

Gambar 4. Kurva in-lier/out-lier data hasil pengukuran $\mathrm{SiO}_{2}$ conto pasir besi IA

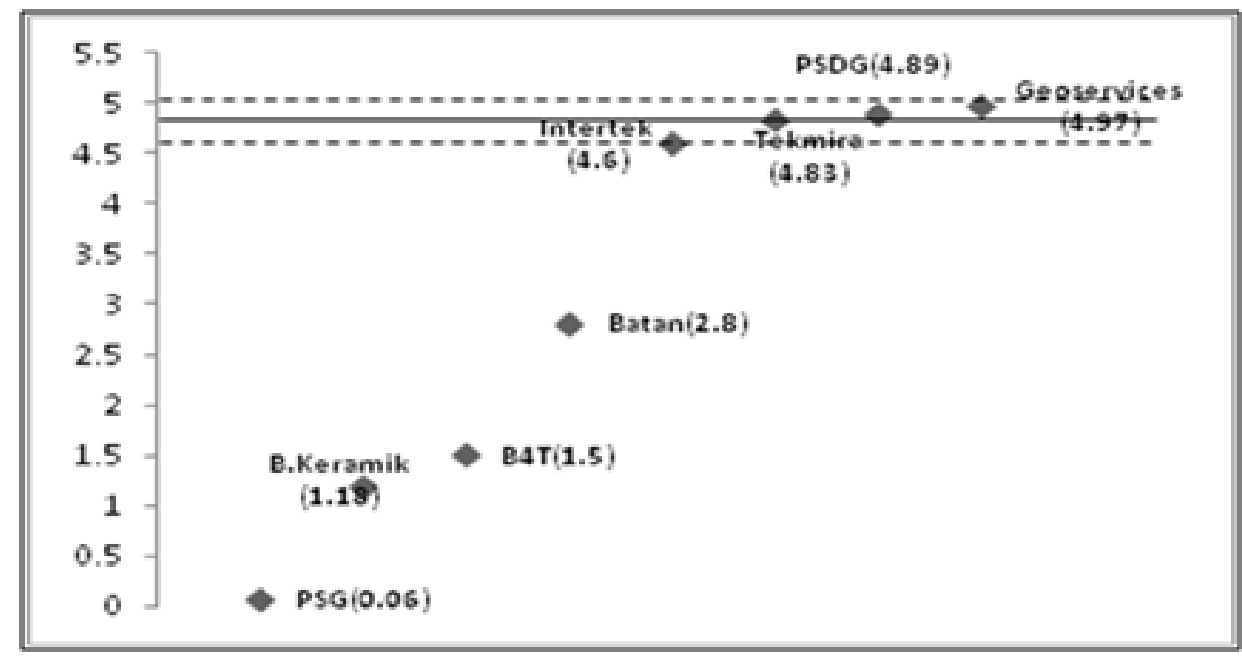

Gambar 5. Kurva in-lier/out-lier data hasil pengukuran MgO conto pasir besi IA 


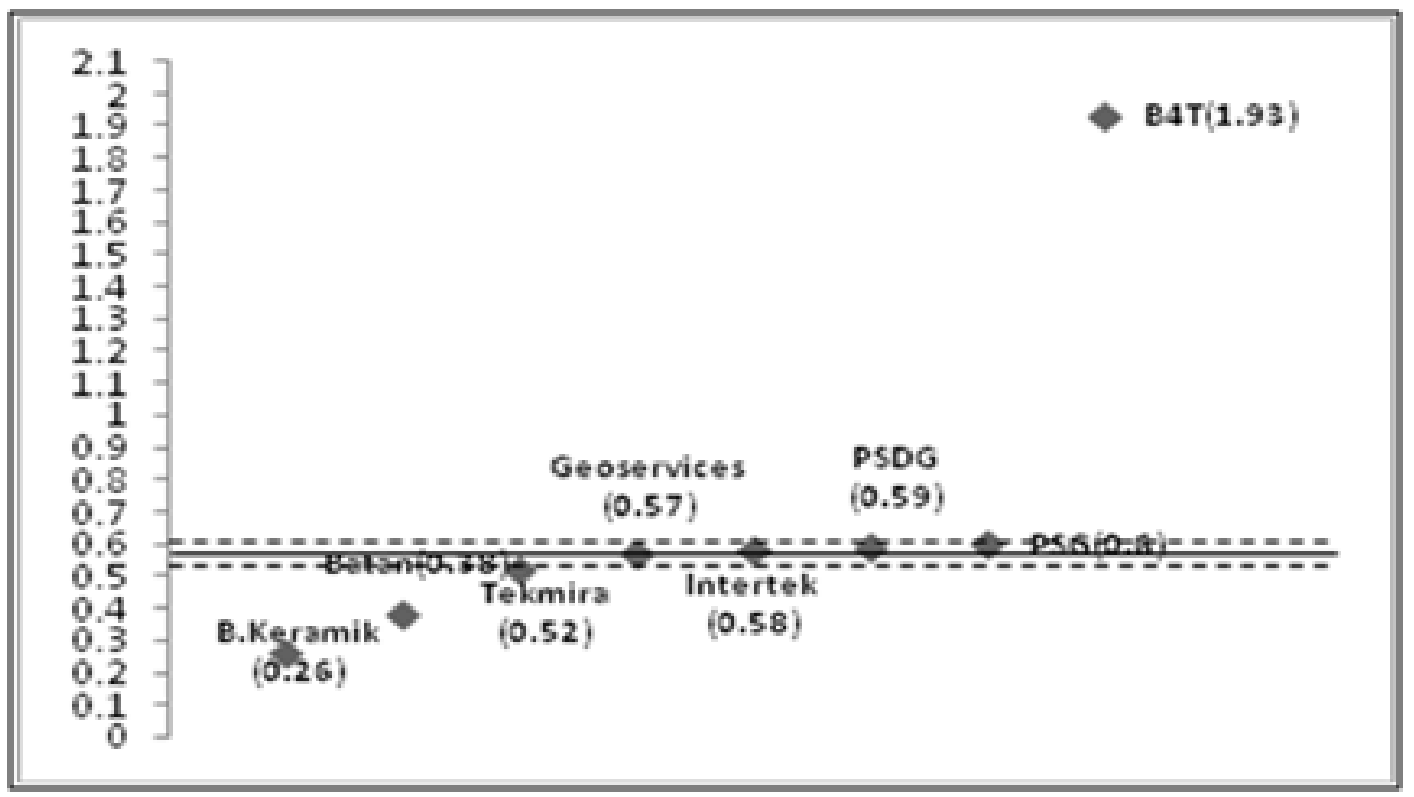

Gambar 6. Kurva in-lier/out-lier data hasil pengukuran $\mathrm{TiO}_{2}$ conto pasir besi IA

Tabel 14. Presisi eksternal hasil analisis kimia conto pasir besi IIA

\begin{tabular}{|c|c|c|c|c|c|c|c|c|c|c|c|c|c|c|c|}
\hline \multirow{2}{*}{$\begin{array}{c}\text { LAB } \\
\text { PENGUJI }\end{array}$} & \multicolumn{15}{|c|}{ HASIL ANALISIS (\%) } \\
\hline & Fe total & $\mathrm{Fe}_{2} \mathrm{O}_{3}$ & $\mathrm{FeO}$ & $\mathrm{TiO}_{2}$ & $\mathrm{Al}_{2} \mathrm{O}_{3}$ & MgO & MnO & $\mathrm{CaO}$ & $\mathrm{K}_{2} \mathrm{O}$ & $\mathrm{Na}_{2} \mathrm{O}$ & $\mathbf{P}$ total & $S$ total & $\mathrm{SiO}_{2}$ & $\mathrm{H}_{2} \mathrm{O}^{-}$ & LOI \\
\hline PSG & 22,78 & 19,05 & 12,26 & 3,93 & * & * & 0,51 & 11,01 & 0,66 & $2,20^{*}$ & 0,01 & 0,20 & 33,87 & 0,08 & - \\
\hline Intertek & 23,79 & * & * & 3,42 & 9,21 & 6,39 & 0,46 & 9,00 & 0,73 & 1,39 & 0,39 & 0,01 & 35,17 & 0,10 & 0,10 \\
\hline B4T & - & * & - & * & * & * & * & * & * & * & 0,01 & 0,01 & * & - & - \\
\hline Balai Keramik & * & * & 14,76 & * & * & * & * & * & 0,79 & * & 0,01 & 0,18 & 35,82 & 0,77 & 0,02 \\
\hline Tekmira & 27,00 & $26,3^{*}$ & 11,10 & 4,16 & 8,09 & 6,78 & 0,39 & 8,08 & 0,70 & 1,49 & - & - & 32,80 & 0,21 & - \\
\hline Geoservices & 24,77 & * & - & 3,55 & 9,21 & 6,76 & 0,45 & 9,13 & 0,76 & 1,61 & 0,18 & 0,03 & 35,70 & 0,01 & $-0,84$ \\
\hline Batan & 20,17 & - & - & * & 5,51 & $2,84^{*}$ & 0,31 & * & * & 1,29 & - & - & * & - & - \\
\hline PSDG & 24,37 & 20,21 & 13,18 & 3,64 & 9,48 & 6,38 & 0,47 & 9,21 & 0,67 & 1,56 & 0,15 & 0,03 & 34,28 & 0,15 & 0,69 \\
\hline Rataan = & 23,81 & 19,63 & 12,83 & 3,74 & 8,30 & 6,58 & 0,43 & 9,29 & 0,72 & 1,47 & 0,16 & 0,03 & 34,61 & 0,13 & 0,69 \\
\hline$S D=$ & 2,268 & - & - & 0,300 & 1,649 & 0,222 & 0,071 & 1,065 & 0,051 & 0,129 & - & - & 1,175 & - & - \\
\hline $\begin{array}{r}\text { Presisi }= \\
\left(\mathbf{s d}^{*} t_{n ; \alpha / 2} / \sqrt{ } n\right)\end{array}$ & 2,269 & - & - & 0,345 & 1,895 & 0,309 & 0,071 & 1,224 & 0,051 & 0,149 & - & - & 1,350 & - & - \\
\hline$t_{n ; 0.025}$ & 2,45 & - & - & 2,57 & 2,57 & 2,78 & 2,45 & 2,57 & 2,45 & 2,57 & - & - & 2,45 & - & - \\
\hline $\mathrm{n}$ & 6 & - & - & 5 & 5 & 4 & 6 & 5 & 6 & 5 & - & - & 6 & - & - \\
\hline
\end{tabular}

Gambar-gambar kurva in-lier/out-lier di atas menggambarkan ketepatan hasil analisa dari masing-masing laboratorium yang ditunjuk untuk menganalisis conto pasir besi IA.Semakin jauh data dari nilai rataan (digambarkan dengan garis penuh pada kurva) maka semakin tidak tepat hasil pengukurannya. Pada semua gambar kurva di atas, Laboratorium PSDG ditunjukkan masuk dalam kategori in-lier. Beberapa parameter seperti $\mathrm{Fe}_{2} \mathrm{O}_{3}, \mathrm{FeO}, \mathrm{P}$ total, $\mathrm{S}_{\text {total, }}$ $\mathrm{H}_{2} \mathrm{O}^{-}$, dan $\mathrm{L}_{\mathrm{o}} \mathrm{l}$, hasil pengukurannya tidak disajikan dalam kurva out-lier/in-lier karena data yang didapatkan tidak lolos dalam uji pencilan data.

Pada masing-masing gambar kurva, data yang terletak antara dua garis putusputus dikatakan in-lier, sedangkan data yang terletak di luar antara dua garis putus-putus dikatakan out-lier.

\section{Conto pasir besi IIA}

Data hasil uji presisi eksternal hasil analisis kimia conto pasir besi IIA ditunjukkan dalam Tabel 14. 
Tabel 15. Presisi eksternal hasil analisa kimia conto pasir besi VA

\begin{tabular}{|c|c|c|c|c|c|c|c|c|c|c|c|c|c|c|c|}
\hline \multirow{2}{*}{$\begin{array}{c}\text { LAB } \\
\text { PENGUJI }\end{array}$} & \multicolumn{15}{|c|}{ HASIL ANALISIS (\%) } \\
\hline & Fe total & $\mathrm{Fe}_{2} \mathrm{O}_{3}$ & $\mathrm{FeO}$ & $\mathrm{TiO}_{2}$ & $\mathrm{Al}_{2} \mathrm{O}_{3}$ & MgO & MnO & $\mathrm{CaO}$ & $\mathrm{K}_{2} \mathrm{O}$ & $\mathrm{Na}_{2} \mathrm{O}$ & $P$ total & $S$ total & $\mathrm{SiO}_{2}$ & $\mathrm{H}_{2} \mathrm{O}^{-}$ & LOI \\
\hline PSG & 47,59 & 40,95 & 24,58 & 9,10 & * & * & 0,43 & 3,00 & 0,19 & 0,66 & 0,01 & 0,10 & * & 0,04 & - \\
\hline Intertek & 51,05 & * & * & 7,61 & 4,54 & 3,36 & 0,62 & 2,66 & 0,18 & * & 0,42 & 0,01 & 8,88 & 0,10 & 0,10 \\
\hline B4T & - & * & - & 9,98 & * & * & * & * & * & * & 0,01 & 0,01 & 10,75 & - & - \\
\hline Balai Keramik & * & 44,47 & * & * & * & * & * & * & * & * & 0,01 & 0,36 & * & 0,54 & 0,02 \\
\hline Tekmira & 52,60 & * & * & 9,28 & 4,13 & 3,52 & 0,55 & 2,43 & 0,16 & 0,61 & 0,15 & - & * & 0,14 & - \\
\hline Geoservices & 49,99 & * & - & 7,87 & 4,56 & 3,74 & 0,62 & 2,73 & 0,22 & 0,62 & 0,20 & 0,08 & 9,30 & 0,10 & $-2,46$ \\
\hline Batan & 50,57 & - & - & * & 2,60 & $2,14^{*}$ & 0,43 & * & 0,11 & * & - & - & * & - & - \\
\hline PSDG & 50,97 & 44,06 & 25,86 & 7,69 & 4,92 & 3,53 & 0,63 & 2,47 & 0,20 & 0,48 & 0,17 & 0,05 & 9,36 & 0,19 & 0,51 \\
\hline Rataan $=$ & 50,46 & 43,16 & 25,22 & 8,59 & 4,15 & 3,54 & 0,55 & 2,66 & 0,18 & 0,59 & 0,17 & 0,07 & 9,57 & 0,19 & 0,51 \\
\hline$S D=$ & 1,653 & - & - & 0,996 & 0,910 & 0,156 & 0,095 & 0,229 & 0,038 & 0,078 & - & - & 0,814 & - & - \\
\hline $\begin{array}{r}\text { Presisi }= \\
\left(\mathbf{s d}^{*} t_{n ; \alpha / 2} / \sqrt{n}\right)\end{array}$ & 1,653 & - & - & 0,996 & 1,046 & 0,217 & 0,095 & 0,263 & 0,038 & 0,108 & - & - & 1,131 & - & - \\
\hline$t_{n ; 0.025}$ & 2,45 & - & - & 2,45 & 2,57 & 2,78 & 2,45 & 2,57 & 2,45 & 2,78 & - & - & 2,78 & - & - \\
\hline $\mathrm{n}$ & 6 & - & - & 6 & 5 & 4 & 6 & 5 & 6 & 4 & - & - & 4 & - & - \\
\hline
\end{tabular}

Tabel 15. Presisieksternal hasil analisis kimia conto pasir besi VA

\begin{tabular}{|c|c|c|c|c|c|c|c|c|c|c|c|c|c|c|c|}
\hline \multirow{2}{*}{$\begin{array}{c}\text { LAB } \\
\text { PENGUJI }\end{array}$} & \multicolumn{15}{|c|}{ HASIL ANALISIS } \\
\hline & Fe total & $\mathrm{Fe}_{2} \mathrm{O}_{3}$ & $\mathrm{FeO}$ & $\mathrm{TiO}_{2}$ & $\mathrm{Al}_{2} \mathrm{O}_{3}$ & MgO & MnO & $\mathrm{CaO}$ & $\mathrm{K}_{2} \mathrm{O}$ & $\mathrm{Na}_{2} \mathrm{O}$ & $P$ total & $S$ total & $\mathrm{SiO}_{2}$ & $\mathrm{H}_{2} \mathrm{O}^{-}$ & LOI \\
\hline PSG & * & 38,67 & 20,27 & 7,38 & * & * & 0,60 & * & 0,31 & 0,82 & 0,01 & 0,10 & 16,24 & 0,05 & - \\
\hline Intertek & * & * & * & 6,18 & 5,85 & * & 0,58 & * & 0,34 & 0,58 & * & 0,00 & 17,62 & 0,20 & 0,10 \\
\hline B4T & - & * & - & 9,37 & * & * & * & 2,42 & 0,06 & 0,04 & 0,01 & 0,01 & * & - & 0,00 \\
\hline Balai Keramik & 47,95 & * & 20,52 & * & * & * & * & 1,91 & 0,90 & 3,22 & 0,01 & 0,39 & 14,21 & 0,38 & 0,02 \\
\hline Tekmira & 47,50 & 39,00 & 25,50 & 7,91 & 3,09 & 9,15 & 0,36 & 1,24 & 0,10 & 0,39 & - & - & 12,45 & 0,15 & - \\
\hline Geoservices & 45,22 & * & - & 7,16 & 3,35 & 8,84 & 0,44 & 1,41 & 0,02 & 0,26 & 0,02 & 0,07 & 16,58 & 0,05 & $-2,66$ \\
\hline Batan & * & - & - & * & 1,88 & 5,07 & * & * & 0,02 & 0,07 & - & - & * & - & - \\
\hline PSDG & 46,71 & 35,72 & 27,85 & 7,58 & 3,72 & 8,42 & 0,46 & 1,38 & 0,05 & 0,12 & 0,02 & 0,06 & 13,17 & 0,06 & 0,56 \\
\hline Rataan $=$ & 46,85 & 37,80 & 23,54 & 7,60 & 3,58 & 7,87 & 0,49 & 1,67 & 0,03 & 0,12 & 0,01 & 0,06 & 15,05 & 0,05 & 0,56 \\
\hline$S D=$ & 1,198 & - & - & 1,048 & 1,445 & 1,890 & 0,101 & 0,489 & - & - & 0,005 & - & 2,067 & - & - \\
\hline $\begin{array}{r}\text { Presisi }= \\
\left(\mathbf{s d}^{*} t_{\mathrm{n} ; \alpha / 2} / \sqrt{ } \mathrm{n}\right)\end{array}$ & 1,666 & - & - & 1,048 & 1,661 & 2,350 & 0,116 & 0,562 & - & - & 0,006 & - & 2,067 & - & - \\
\hline$t_{n ; 0.025}$ & 2,78 & - & - & 2,45 & 2,57 & 2,78 & 2,57 & 2,57 & - & - & 2,57 & - & 2,45 & - & - \\
\hline $\mathrm{n}$ & 4 & - & - & 6 & 5 & 4 & 5 & 5 & - & - & 5 & - & 6 & - & - \\
\hline
\end{tabular}

\section{Conto pasir besi VA}

Data hasil uji presisi eksternal dari hasil analisis kimia conto pasir besi VA ditunjukkan dalam Tabel 15.

\section{Conto pasir besiENDE-5}

Data hasil uji presisi eksternal dari hasil analisis kimia conto pasir besi ENDE-5 ditunjukkan dalamTabel 16.

\section{Penutup}

Analisis kimia di delapan laboratorium terhadap empat jenisconto pasir besi menghasilkan bahan acuan baku pasir besi dengan konsentrasi ( $\%$ berat) berkisar antara $23,81 \%-50,46 \% \quad \mathrm{Fe}_{\text {total }}$, berkisar antara $19,63 \%-43,16 \% \mathrm{Fe}_{2} \mathrm{O}_{3}$, berkisar antara $19,90 \%-25,22 \% \mathrm{FeO}$, berkisar antara $3,74 \%-7,60 \% \mathrm{TiO}_{2}$. Secara detail bahan acuan baku pasir besi yang dihasilkan mempunyai kandungan unsur $\mathrm{Fe}_{\text {total }}, \mathrm{Fe} 2 \mathrm{O} 3$, $\mathrm{FeO}, \mathrm{TiO}_{2}, \mathrm{Al}_{2} \mathrm{O}_{3}, \mathrm{MgO}, \mathrm{MnO}, \mathrm{CaO}, \mathrm{K}_{2} \mathrm{O}, \mathrm{MnO}$ dan $\mathrm{SiO}_{2}$, seperti terlihat pada Tabel 17.

Hasil analisis dari delapan laboratorium pada umumnya mempunyai presisi $<2$, kecuali untuk unsur $\mathrm{MgO}$ pada conto ENDE5 mempunyai presisi 2,35 , hal ini dikarenakan hanya empat hasil analisis yang datanya dapat diuji statistik dari delapan laboratorium yang melaksanakan pengujian unsur tersebut. 


\section{MAKALAH ILMIAH}

Tabel 17. Komposisi unsur pada bahan acuan baku pasir besi yang dihasilkan

\begin{tabular}{|c|c|c|c|c|c|c|c|c|}
\hline \multirow{2}{*}{ Unsur } & \multicolumn{2}{|c|}{ IA } & \multicolumn{2}{|c|}{ IIA } & \multicolumn{2}{|c|}{ VA } & \multicolumn{2}{|c|}{ ENDE-5 } \\
\hline & C (\%) & presisi & C (\%) & presisi & C (\%) & presisi & C (\%) & presisi \\
\hline Fe total & 42,05 & 0,695 & 23,81 & - & 50,46 & - & 46,85 & - \\
\hline $\mathrm{Fe}_{2} \mathrm{O}_{3}$ & 38,57 & - & 19,63 & - & 43,16 & - & 37,80 & - \\
\hline $\mathrm{FeO}$ & 19,90 & - & 12,83 & - & 25,22 & - & 23,54 & - \\
\hline $\mathrm{TiO}_{2}$ & 6,89 & 0,652 & 3,74 & 0,345 & 8,59 & 0,996 & 7,60 & - \\
\hline $\mathrm{Al}_{2} \mathrm{O}_{3}$ & 5,74 & 0,633 & 8,30 & - & 4,15 & - & 3,58 & - \\
\hline $\mathrm{MgO}$ & 4,83 & 0,223 & 6,58 & 0,309 & 3,54 & 0,217 & 7,87 & 2,350 \\
\hline MnO & 0,57 & 0,036 & 0,43 & 0,071 & 0,55 & 0,095 & 0,49 & 0,116 \\
\hline $\mathrm{CaO}$ & 5,27 & 0,614 & 9,29 & - & 2,66 & 0,263 & 1,67 & 0,562 \\
\hline $\mathrm{K}_{2} \mathrm{O}$ & 0,33 & 0,025 & 0,72 & 0,051 & 0,18 & 0,038 & - & - \\
\hline $\mathrm{Na}_{2} \mathrm{O}$ & 0,77 & 0,144 & 1,47 & 0,149 & 0,59 & 0,108 & - & - \\
\hline $\mathbf{P}$ total & - & - & - & - & - & - & 0,01 & 0,006 \\
\hline $\mathbf{S}$ total & - & - & - & - & - & - & - & - \\
\hline $\mathrm{SiO}_{2}$ & 16,68 & 1,075 & 34,61 & 1,350 & 9,57 & 1,131 & 15,05 & 2,067 \\
\hline $\mathrm{H}_{2} \mathrm{O}^{-}$ & - & - & - & - & - & - & 0,05 & - \\
\hline LOI & - & - & - & - & - & - & - & - \\
\hline
\end{tabular}

Angka-angka konsentrasi major element dalam conto pasir besi tersebut didapatkan dari hasil kolaborasi 8 laboratorium kimia.

\section{Ucapan Terima Kasih}

Penulis mengucapkan terima kasih kepada semua pihak yang telah membantu baik dalam tahap pelaksanaan pembuatan bahan acuan baku maupun pada saat proses penerbitan makalah ini. Terutama kami sampaikan ucapan terima kasih kepada Ir. Kasbani, M.Sc.yang telah memberikan arahan dan koreksinya juga kepada Ir.Herry Rodiana Eddy, M.Si. yang telah memberikan masukan serta koreksinya, sehingga makalah ini dapat diterbitkan.

\section{DAFTAR PUSTAKA}

Anonim, 2006, Penyusunan Prosedur Analisis Laboratorium Fisika dan Kimia Terpadu Conto Pasir Besi, Pusat Sumber Daya Geologi, Bandung.

Anonim, 2004, Pedoman Perhitungan Statistika Untuk Uji Profisiensi, Penerbit Komite Akreditasi Nasional, DP.01.34, Jakarta.

Edelgard Hund, D. Luc Massart, Johanna Smeyers-Verbeke, 2000, Inter-laboratory studies in analytical chemistry, Analytica Chimica Acta 423 (2000) 145-165.

Soedigdo, S.DanSoedigdo, P., 1977,Pengantar Cara Statistika Kimia, Penerbit ITB, Bandung. 